\title{
The worker protection justification: Lessons from consumer law
}

\author{
Catherine Barnard, Trinity College, Cambridge \\ 'Overriding reasons relating to the public interest already recognised by the \\ Court include the protection of workers'1
}

\section{A. Introduction}

Much consideration has been given to the face of the consumer in EU free movement and competition law. ${ }^{2}$ Much less time has been devoted to examining the face of the worker. This is surprising. The worker has been directly recognised by the Treaties since the inception of the EU, most obviously in respect of Article 45 TFEU on the free movement of workers and also Article 157 TFEU on 'equal pay for male and female workers'. Workers have also been recognised in other ways. They were the intended beneficiaries of the single market, as Article $117 \mathrm{EEC}$ (now amended Article 151 TFEU) made clear:
Member States agree upon the need to promote improved working conditions and an improved standard of living for workers ...They believe that such a development will ensue not only from the functioning of the common market, ... but also from the procedures provided for in this Treaty.

Article 117 EEC was important for two reasons: first, it recognised that workers should enjoy (increasingly good) employment rights; and second, that migrant workers specifically, and the

\footnotetext{
*I am very grateful for the discussion with the participants in the seminar on justifications at City University in February 2014, as well as to those on the Czech Common Law Society Summer School, July 2014, to Niall $\mathrm{O}$ 'Connor and to the editors of this volume for their careful comments.

1 Joined cases C-49/98, C-50/98, C-52/98 to C-54/98 and C-68/98 to C-71/98 Finalarte [2001] ECR I-7831, para. 33.

${ }^{2}$ See eg A. Albors-Llorens and A. Jones, 'The images of the "Consumer" in EU Competition Law' in D. Leczykiewicz and S. Weatheril The Images of the Consumer in EU Law: Legislation, Free Movement and Competition Law (Oxford, Hart Publishing, 2016); S. Weatherill, 'Consumer Policy' in P. Craig and G. de Búrca, Evolution of EU Law, (Oxford, OUP, 2011).
} 
working population more generally, would benefit from the opportunities created by the common, now single, market.

Yet Article 117 EEC disguised a problem: how to reconcile the protection of social rights (largely delivered at national level) with the deregulatory push mandated at EU level by the four freedoms. For many years the Court of Justice was able to avoid adjudicating on this clash, usually by finding that EU law did not apply. ${ }^{3}$ So, for example, in Oebel, ${ }^{4}$ the defendant, accused of breaching restrictions on night work limits, complained that those rules interfered with free movement of goods. The Court rejected his argument. It said that the national rules did not have the effect of restricting free movement of goods between Member States; and since trade within the EU remained possible at all times, there was no breach of Article 34 TFEU.

Where avoidance techniques proved impossible, the Court created the 'worker protection' public interest requirement to allow states to justify their rules, which they could do relatively easily, at least in the early days. So, in the early case of $W e b b,{ }^{5}$ the Court found that the national rule, requiring temp agencies to be licensed, breached Article 56 TFEU, but could be justified on the grounds of worker protection. States could refuse licences where there was reason 'to fear that such activities may harm good relations on the labour market or that the interests of the workforce affected are not adequately safeguarded'. ${ }^{6}$

The accession to the EU of states, such as Spain, Portugal, Greece and, most recently, the Eastern European states, forced the Court to rethink its somewhat laissez-faire approach to states' justification of national laws on worker protection grounds. Workers in these new countries (and their employers) saw access to the (labour) markets of the wealthier countries in northern Europe as a way of improving their own standard of living. Barriers put in the way by host state laws on workers' rights potentially impeded these opportunities.

This changing context set up the conditions for a clash between, on the one hand, the interests of national workers (usually in the northern European states) who wanted to see their jobs, and terms and conditions of employment protected, and, on the other, the interests of migrant workers (usually from the Eastern and Southern states) who wanted freer (unrestricted?) access to the

\footnotetext{
${ }^{3}$ See eg Case C-190/98 Graf v Filzmoser Maschinenbau GmbH [2000] ECR I-493; Case C-67/96 Albany International BV v Stichting Bedrijfspensioenfonds Textielindustrie [1999] ECR I-5751.

${ }^{4}$ Case 155/80 Oebel [1981] ECR 1993

${ }^{5}$ Case 279/80 Webb [1981] ECR 3305.

${ }^{6}$ Ibid, para. 19
} 
markets in those host northern European states. ${ }^{7}$ The question for the Court was how to strike the balance between these two interests.

\section{The consumer protection case law}

Some, rather similar, battles had already been fought in the field of consumer protection, albeit with the Court working against a more incomplete canvas. Outside agriculture and competition law, consumers were not specifically recognised by the Treaty of Rome. Yet in the famous 1979 decision of Cassis de Dijon, ${ }^{8}$ two years before its analogue in Webb, the Court said that states were, in certain circumstances, free to protect the interests of national consumers (despite the absence of any mention of consumers in Article 36 TFEU). Cassis de Dijon concerned German rules requiring fruit liqueurs to have a minimum alcohol content of $25 \%$. French cassis had an alcohol content of only 15 $20 \%$. The German government justified its $25 \%$ rule for various public health/consumer protection reasons, including the fact that the German consumer was less likely to get drunk on the higher alcohol (German) drink. The Court did recognise that Germany could, in principle, invoke the consumer protection justification to protect German consumers from the error of their ways. However, the combined application of the mutual recognition and proportionality principles resulted in a decision favouring market integration and the removal of barriers (the $25 \%$ rule) which had been created by the host state in the name of consumer protection.

Cassis de Dijon and the subsequent case law forced the Court to address the question as to whether, and how, consumers should be protected. Some argued that the Court should adopt a restrictive interpretation of the four freedoms and so uphold paternalist national rules protecting consumers (such as the (not very bright) German consumers who risked drinking more of the lower alcohol fruit liqueur in the absence of the protective German rule). This paternalist approach supports the consumer protection model which, in turn, speaks to one of the objectives of EU law, namely ensuring a high level of consumer protection. ${ }^{9}$ However, upholding the consumer protection justification leads to less free movement of goods and services and so less competition, resulting in (German) consumers having less choice of goods to purchase (ie they are denied the choice between the German fruit liqueur with $25 \%$ alcohol or the French cassis with only $20 \%)$. In other words, the aggregate welfare of consumers would be reduced.

\footnotetext{
${ }^{7} \mathrm{C}$. Barnard, 'The protection of fundamental social right after Lisbon: A Question of Conflicts of Interests' in S. de Vries, U. Bernitz and S. Weatherill, The Protection of Fundamental Rights in the EU After Lisbon (Oxford, Hart Publishing, 2013).

${ }^{8}$ Case C-120/78 Cassis de Dijon [1979] ECR 649.

${ }^{9}$ See eg Art. 12 TFEU and Art. 114(3) TFEU.
} 
So, another school of thought argued that the Court should adopt an expansive reading of the free movement provisions, using them to strike down national rules drafted to protect consumers. This is done to ensure that the wider $E U$ interest in securing the benefits of the single market for the consumer body as a whole. This wider interest is about consumers having greater choice of products and enjoying the benefits of greater competition between those products (cheaper prices and/or better quality goods). This, more liberal, reading of the Treaty provisions is described as embodying the consumer welfare approach.

The genesis of the concept of consumer welfare lies in the field of competition law. For the Commission, 'consumer welfare' means the delivery of direct benefits to consumers through 'lower prices, better quality and a wider choice of new or improved goods and services' ${ }^{10}$ This approach has been endorsed by the General Court in GlaxoSmithKline ${ }^{11}$ (albeit subsequent judicial decisions have clouded the water as to what precisely is the objective of EU competition law). ${ }^{12}$

A consumer welfare approach would suggest that any interference with the free movement principle by national legislation adopted on the grounds of consumer protection (ie the paternalist approach) should be scrutinised very carefully. And this is the position the Court of Justice has generally taken. Usually, it finds that the (Union interest) in consumer welfare prevails over the national interest in consumer protection and thus the free movement principle trumps the paternalist state interest in consumer protection. ${ }^{13}$ This may be due in part to a (neo)-liberal bias in the Court's judgments but it may also be due, as Poiares Maduro has argued, to wider EU control over Member State regulation in the common market. ${ }^{14}$

10 See para. 5 of the Guidance on the Commission's enforcement priorities in applying Article 82 of the EC Treaty [now Article 102 TFEU] to abusive exclusionary conduct by dominant undertakings ((OJ [2009] C 45/7).

${ }^{11}$ Case T-168/01 GlaxoSmithKline Services v Commission [2006] ECR II-2969 at paras. 118 and 121-122.

${ }^{12}$ Case C-52/09 Konkurrensverket v. TeliaSonera Sverige AB [2011] ECR I- 527, para. 22 'the function of those rules [Article 102 TFEU] is precisely to prevent competition from being distorted to the detriment of the public interest, individual undertakings and consumers, thereby ensuring the well-being of the European Union'. See further Albors-Llorens and Jones, above n. 2.

${ }^{13}$ There are many examples but see eg Case C-315/92 Clinique [1994] ECR I-317; Case C-470/93 Mars [1995] ECR I-1923.

${ }^{14}$ M. Poiares Maduro, We the Court: The European Court of Justice and the European Economic Constitution (Oxford, Hart Publishing, 1998). See also I. H Eliasoph, 'A "Switch in Time" for the European Community? Lochner Discourse and the Recalibration of Economic and Social Rights in Europe' (2010) Columbia Journal of European Law 468. 


\section{Worker protection v worker welfare}

This chapter draws on the consumer literature to develop a distinction between notions of (1) worker protection and (2) worker welfare as a way of analysing the outcomes of the Court's decisions in those cases where states have raised 'worker protection' as a public interest requirement to justify their rules. Where the Court recognises and upholds worker protection as a justification, it is essentially accepting that in the circumstance of this particular case the state's paternalist interest in ensuring decent working conditions takes precedence over the wider EU interest in the realisation of a single market.

By contrast, when the Court rejects the worker protection justification, it may be prioritising the Union interest in worker welfare. To labour lawyers 'worker welfare' may be synonymous to 'worker protection' but that is not the sense in which the term is being used in this chapter. ${ }^{15}$ As used here, the term 'worker welfare' (the term has been deliberately chosen to reflect the parallels with the consumer case law) means allowing workers across the EU the opportunity to work in whichever state they choose and on the terms dictated by the market (unless EU social law intervenes to provide specific protection). In other words, where the Court rejects the worker protection justification it may be recognising that in the circumstances of this particular case, the Union interest in the realisation of a single market (with the opportunities this brings for workers from poorer states to improve their life chances in wealthier states) should take precedence over the host state's paternalist interest to protect (national) workers (and their jobs).

As we shall see, a strict quantitative approach to the cases, suggests that the Court does indeed favour worker welfare over worker protection, just as it does consumer welfare over consumer protection (section C). However, as we shall also see, a more qualitative reading of the cases leads to more nuancedconclusions. When only the (non-migrating) employer stands to gain from invoking the free movement principle, there is some evidence Court favours the state interest in worker protection (section D). By contrast, when migrants are exercising their rights of free movement

\footnotetext{
${ }^{15}$ One other note for labour lawyers: the search of the Court's jurisprudence on 'worker protection' did not reveal any cases which engaged with the question of who is a 'worker'. This is a vexed question in national employment law and, increasingly, in EU substantive law because it raises the fundamental question of the personal scope of the protection. Under English law, for example, the term 'worker' is broader than 'employee'. Under Article 157 TFEU on equal pay, the term worker may also include the dependent 'selfemployed'. Generally, these issues are not engaged with at all when it comes to considering the worker protection justification, albeit in Case C-577/10 Commission v Belgium the Court talked of the public interest requirement of 'protecting workers, including self-employed service providers'.
} 
under Article 45 TFEU or where businesses are exercising their rights to freedom of establishment in a state with lower labour costs under Article 49 TFEU, or exercising freedom to provide services using posted workers under Article 56 TFEU, the Court is forced to balance the state interest in worker protection with the wider Union interest in worker welfare. It will be argued that in these cases the Court tends to favour worker welfare unless the host state raises a genuine worker protection concern and can show the measures it takes are proportionate. It will therefore be argued that while the presumption in the free movement case law is in favour of worker welfare, particularly where national rules are overtly or covertly protectionist, where there are genuine concerns for workers (both national and migrant/posted or just migrant/posted), the Court will upheld the worker protection justification or may do so in the future if the rules were modified in some way. So the Court's position is in fact less biased in favour of worker welfare than a pure quantitative analysis might suggest (section $\mathrm{E}$ ).

This chapter concludes with the suggestion that while the consumer case law has helped to tease out some of the nuances as to when the worker protection justification is successfully invoked, it will be argued that the parallels are not as robust as would first appear (section F).

\section{Methodology}

The research question, then, is whether the Court's case law does lead to the prioritisation of worker welfare over worker protection, in much the same way as the Court's consumer case law generally prioritises consumer welfare over consumer protection. To help find an answer to this question, a simple methodology was used. A search was made in the Curia database ${ }^{16}$ of all cases up to 1 July 2015, for the phrases 'worker protection' and 'employee protection', and the analogues such as 'protection of workers' and 'protection of employees'. A search was also made for cases where the phrase 'social protection of workers' was used (this often came up in the posting of workers cases, which form the bulk of the cases in this data set), which seems to be a synonym for 'worker protection' ${ }^{17}$ This search did not, however, catch all the cases (most notable by their omission were the judgments in Rush Portuguesa ${ }^{18}$ and Van der Elst, ${ }^{19}$ known by the author to be important in this

\footnotetext{
${ }^{16}$ http://curia.europa.eu/.

${ }^{17}$ See eg Case C-515/08 Santos Palhota [2010] ECR I-9133, paras. 46-47. For an earlier example, see Case C

272/94 Guiot [1996] ECR I-1905, para. 16. For an example in the field of workers, see Case C-202/11 Las, para.

28.

${ }^{18}$ Case C-113/89 Rush Portuguesa [1990] ECR 1-1417, paragraph 18.

${ }^{19}$ Case C-43/93 Van der Elst [1994] ECR I-3803.
} 
field). Therefore, a further check was made against the decisions cited in the case law which came up in the Curia database search to ensure that all the main cases had been identified.

Each case was then considered and those concerning the interpretation of EU social policy directives were discarded since they are not relevant to the enquiry about the use of the worker protection justification by states in the free movement context. This left 30 or so cases. These cases were then divided up into (1) those which were the result of Article 258 TFEU enforcement proceedings where an outcome is clear; and (2) those involving an Article 267 TFEU reference, where it may be harder to determine an outcome due to the fact that that it is the national court that makes the final decision on, say, the proportionality of the measure and the final decision of the national court (if any) may not be subsequently reported/available. The Article 258 TFEU cases were then analysed to consider, where possible, if the state won or lost, and why. This quantitative analysis of the case law was then supplemented by a more qualitative analysis of the decisions.

\section{B. The Worker Protection Justification and its Limits}

In order to provide the context for the subsequent discussion, the chapter begins with a brief examination of the worker protection public interest requirement, the contexts in which the term has been invoked, and the limitations on the use of the justification.

\section{The worker protection justification}

\subsection{Developing the worker protection justification}

As we saw in the introduction, the basic settlement at the time of the Treaty of Rome was that social policy was a value to be recognised by the $\mathrm{EU}^{20}$ but actually delivered largely by the Member States. This meant it was inevitable that Member States would invoke worker protection as a justification to defend challenges to their social legislation, and that the Court would eventually have to recognise that justification, as it did in Webb. By the early 1990s, the Court said in Gouda ${ }^{21}$ that 'the protection of workers' was among the list of public interest justifications which it had already recognised:

14.In this respect, the overriding reasons relating to the public interest which the Court has already recognized include professional rules intended to protect recipients of the service ...; protection of intellectual property ...; the protection of workers (Case 279/80 Webb [1981] ECR 3305, paragraph 19; Joined Cases 62/81 and 63/81 Seco v EVI [1982] ECR 223, paragraph

\footnotetext{
${ }^{20}$ See specifically Title III on Social Policy

${ }^{21}$ Case C-288/89 Stichting Collectieve Antennevoorziening Gouda and others v Commissariaat voor de Media [1991] ECR I-4007, paras. 13-14.
} 
14; Case C-113/89 Rush Portuguesa [1990] ECR 1-1417, paragraph $18^{22}$ ); consumer protection ...

15. Lastly, as the Court has consistently held, the application of national provisions to providers of services established in other Member States must be such as to guarantee the achievement of the intended aim and must not go beyond that which is necessary in order to achieve that objective. In other words, it must not be possible to obtain the same result by less restrictive rules.

Since Gouda, the 'worker protection' justification has been recognised by the Court in over 30 cases (see tables 1-3 below). Its existence as an overriding reason in the public interest (ORPI) has also been confirmed by the Services Directive 2006/123 where worker protection sits alongside the consumer protection justification: ${ }^{23}$

The notion [ORPI] as recognised in the case law of the Court of Justice covers at least the following grounds: ... the maintenance of order in society; social policy objectives; the protection of the recipients of services; consumer protection; the protection of workers, including the social protection of workers.

1.2 Extending the worker protection justification

Thus the early case law was clear: worker protection is an important public interest justification which was used by states in the way that labour lawyers would understand it: to justify national laws providing substantive protection to the weaker party (the employee). However, in subsequent cases defendant states tried their luck - or at the very least tried to stretch the contexts in which the worker protection justification could be invoked. For example, in Case C-577/10 Commission v

\footnotetext{
${ }^{22}$ It is not entirely clear why the Court cited para.18 of Rush Portuguesa to justify the worker protection justification since the paragraph seems to say something different: 'Finally, it should be stated, in response to the concern expressed in this connection by the French Government, that [Union] law does not preclude Member States from extending their legislation, or collective labour agreements entered into by both sides of industry, to any person who is employed, even temporarily, within their territory, no matter in which country the employer is established; nor does [Union] law prohibit Member States from enforcing those rules by appropriate means.' Thus, this paragraph could mean that the application of labour law rules to migrant workers (i) does not amount to a restriction on free movement of services or (ii) that it is a restriction, but one which is (always) justified and proportionate.

${ }^{23}$ OJ [2006] L376/36Recital 40.
} 
Belgium, ${ }^{24}$ Belgium tried to bring under the umbrella of the worker protection justification the need to protect the treasury as well as the need to create a level playing field. The Court was prepared, in principle, to accept the Belgian justification:

the objective of combating fraud, particularly social security fraud, and preventing abuse, in particular detecting 'bogus self-employed persons' and combating undeclared work, can form part not only of the objective of the financial balance of social security systems, but also of the objectives of preventing unfair competition and social dumping and protecting workers, including self-employed service providers.

However, the Court stressed that any controls imposed had to comply with the limits imposed by EU law and could not render the freedom to provide services illusory. ${ }^{25}$

An even wider - and more controversial - reading of the worker protection justification ${ }^{26}$ can be seen in Case C-445/03 Commission v Luxembourg, ${ }^{27}$ where the host state, Luxembourg, argued that the worker protection justification included protecting the jobs of home state workers. Specifically, Luxembourg argued that its labour market needed to be protected from 'being disrupted by a flood of workers who are nationals of non-member countries'. ${ }^{28}$ Somewhat surprisingly, given its longstated opposition to the use of justifications to serve economic purposes, ${ }^{29}$ the Court may have recognised this as an aspect of the worker protection justification ${ }^{30}$ : 'the desire to avoid disturbances

${ }^{24}$ EU:C:2012:814, para.45. See also Case C-549/13 Bundesruckerei v Stadt Dortmund EU:C:2014:2235, para. 35, Case C-315/13 De Clercq EU:C:2014:2408, para. 65

${ }^{25}$ Case C-113/89 Rush Portuguesa [1990] ECR I-1417, para. 17

${ }^{26}$ Luxembourg also ran a more traditional argument based on worker protection but this was rejected by the Court because the requirements imposed in connection with obtaining a licence were disproportionate (paras. 29-36)

${ }^{27}$ Case C-445/03 Commission v Luxembourg [2004] ECR I-10191.

${ }^{28}$ Para. 37. See also Case C-168/04 Commission v Austria [2006] ECR I-9041. In this way, the Court echoes the Spaak report: 'The European Commission will decide on the necessary protection measures in order to avoid an inflow of labor which would be dangerous for the standard of living or employment of workers in certain specified industries, without affecting the rights acquired by foreign workers'.

${ }^{29}$ For a full discussion of this subject see S. Arrowsmith, 'Rethinking the Approach to Economic Justifications under the EU's free movement rules' (2015) 68 Current Legal Problems 307.

${ }^{30}$ The doubt relates to the fact that the Court cites para. 13 of Rush Portuguesa, not para. 18 (which was subsequently used as the authority for the worker protection justification), yet para. 13 concerns Article 216 of the Act of Accession (ie a Treaty provision) which was 'intended to prevent disturbances on the employment market following Portugal's accession, both in Portugal and in the other Member States, due to large and 
on the labour market is undoubtedly an overriding reason of general interest' ${ }^{31}$ This point has now been picked up by the UK's New Settlement Decision: ${ }^{32}$

If overriding reasons of public interest make it necessary, free movement of workers may be restricted by measures proportionate to the legitimate aim pursued. Encouraging recruitment, reducing unemployment, protecting vulnerable workers and averting the risk of seriously undermining the sustainability of social security systems are reasons of public interest recognised in the jurisprudence of the Court of Justice of the European Union for this purpose, based on a case by case analysis.

However, the Court is not generally sympathetic to such arguments, or finds ways round them on the facts, as it did in Case C-445/03 Commission v Luxembourg itself. In Case C-445/03 the Court said that 'workers employed by an undertaking established in a Member State and who are deployed to another Member State for the purposes of providing services there do not purport to gain access to the labour market of that second State, as they return to their country of origin or residence after the completion of their work' ${ }^{33}$ In other words posted workers do not enter the Luxembourg labour market and so do not threaten national jobs and so Luxembourg could not take action. In Case C244/04 Commission v Germany, ${ }^{34}$ the Court gave a similar reason to reject a German rule requiring at least one year's prior employment by the posting undertaking in order to ensure 'the protection of workers, the safeguarding of the Member States' prerogatives in respect of access to their employment market and the prevention of social dumping' ${ }^{35}$

\section{Limitations}

As Gouda shows, even where the worker protection justification is successfully invoked, the steps taken must comply with the principle of proportionality (paragraph 15). Subsequent case law has elaborated on the limits on the use by the Member States of the justification, limitations which (unsurprisingly) reveal a number of commonalities with the general case law on justifications. They can be summarised as follows.

immediate movements of workers'. The Luxembourg law dated from 1972; Portugal acceded to the EU in 1986.

${ }^{31}$ Para.38.

32 The UK New Settlement Decision, 18-19 February 2016, section D.(1)(a), emphasis added.

33 lbid.

${ }^{34}$ Case C-244/04 Commission v Germany [2006] ECR I-885.

${ }^{35}$ Para. 57. Cf C-49/98 Finalarte, para. 38 where the national court pointed out the protectionist aim behind the national law but the Court was not swayed: 'that declared intention is not conclusive'. See also case C164/99 Portugaia Construções \{2002] ECR I-787, para. 27. 
First, the Court (usually) requires evidence to support the justification: mere general assertions are not enough. ${ }^{36}$ Secondly and relatedly, the Court requires that there must be a direct link between the national law and the protection of the worker otherwise the justification is not made out; in other words, the national legislation must 'secure the protection of [posted] workers' ${ }^{37}$ So in Seco, ${ }^{38}$ the Court said that an obligation requiring a provider of services to pay employers' contributions to the host State's fund could not be justified where those contributions conferred no social advantage on the workers concerned..$^{39}$ Similarly, in Van der Elst, ${ }^{40}$ as in Case C-445/03 Commission v Luxembourg, the Court rejected the French argument that a Belgian company posting Moroccan workers had to have a French work permit for those Moroccan workers in order to regulate access to the French labour market for workers from non-member countries. ${ }^{41}$ Since those workers did not intend to gain access the French labour market, the justification was not made out. ${ }^{42}$

Thirdly, in the cases on free movement of services, the Court takes into account the protection already provided in the home state when assessing what (further) steps the host state can take. ${ }^{43}$ So in Guiot, a case where the host state required the posting employer to pay employer's contributions to the state's social security fund, the Court said that the public interest of worker protection did not apply where the workers enjoyed 'the same protection, or essentially similar protection, by virtue of employer's contributions already paid by the employer in the Member State of establishment'. ${ }^{44}$ Putting it another way, as the Court did in Arblade, ${ }^{45}$ only if the employer's contributions to the host

\footnotetext{
${ }^{36}$ Case C-112/05 Commission v Germany (Volkswagen) [2007] I-8995, para. 74.

${ }^{37}$ Case C-60/03 Wolff \& Müller GmbH \& Co. KG v José Filipe Pereira Félix [2004] ECR I-9553, para. 38; Case C279/00 Commission v Italy [2002] ECR I-1425, para. 22.

${ }^{38}$ Joined Cases 62 and 63/81 Société anonyme de droit français Seco and Société anonyme de droit français Desquenne \& Giral v Etablissement d'assurance contre la vieillesse et l'invalidité [1982] ECR 223.

${ }^{39}$ Para. 10.

${ }^{40}$ Case C-43/93 Van der Elst [1994] ECR I-3803.

${ }^{41}$ Para. 20.

42 Para. 21

${ }^{43}$ Case C-165/98 Criminal proceedings against André Mazzoleni and Inter Surveillance Assistance SARL [2001] ECR I-2189, para. 40

${ }^{44}$ Case 272/84 Criminal proceedings against Michel Guiot and Climatec SA [1996] 1-1905, paras. 18-19.

45 Joined Cases C-369/96 and C-376/96 Criminal proceedings against Jean-Claude Arblade and Arblade \& Fils SARL and Bernard Leloup, Serge Leloup and Sofrage SARL [1999] I-8453.
} 
State's fund conferred on workers an advantage capable of providing them with real additional protection would it be possible to justify the payment of the contributions in question. ${ }^{46}$

There are other limitations on the use of the worker protection justification which the Court has referred to in the worker protection cases: considerations of a purely administrative nature cannot make lawful a restriction of the freedom to provide services justified on the grounds of worker protection; ${ }^{47}$ nor can those of a purely economic nature (although as we have seen, the Court is increasingly ambivalent on this). ${ }^{48}$ Measures taken to achieve the worker protection objective must also not discriminate between the public and private sectors, ${ }^{49}$ must be consistent, ${ }^{50}$ transparent, $^{51}$ and, of course, proportionate.

\section{The outcome in cases where states invoke worker protection} This case law considered so far already shows that there can be different understandings of the worker protection justification, and that the Court may or may not accept either the justification of the proportionality of the measures. We turn now to consider more systematically the outcomes in the cases where the worker protection justification has been raised by states.

There have been 31 cases where the state has invoked 'worker protection' or its analogues as a justification to restrict free movement. Of those 31 cases, there were nine enforcement proceedings (see table 1, column 1) and 22 preliminary references (see table 2 , column 1 ). Of the nine enforcement proceedings in only one did the defendant Member State win (Case C-490/04 Commission v Germany) and there only in part. In all other cases the state lost because it offered no justification, or because the justification was not made out, or, more commonly, the state's actions were not proportionate (see table 1, columns 2-6).

\begin{tabular}{|c|c|c|c|c|c|}
\hline Case & Freedom & $\begin{array}{l}\text { State } \\
\text { wins }\end{array}$ & $\begin{array}{c}\text { State loses: } \\
\text { No } \\
\text { justification } \\
\text { offered } \\
\text { or available }\end{array}$ & $\begin{array}{c}\text { State loses: } \\
\text { Justification } \\
\text { not } \\
\text { made out }\end{array}$ & $\begin{array}{c}\text { State loses: } \\
\text { Measure } \\
\text { disproportionate }\end{array}$ \\
\hline
\end{tabular}

${ }^{46}$ Para. 54.

${ }^{47}$ Case C-493/99 Commission v Germany [2001] I-8163 para. 21.

${ }^{48}$ Case C-164/99 Portuguaia Construções [2002] ECR I-787.

${ }^{49}$ Case C-549/13 Bundesruckerei v Stadt Dortmund EU:C:2014:2235, para. 32.

${ }^{50}$ Case C-79/01 Payroll Data services [2002] ECR I-8923, para. 37.

${ }^{51}$ Case C-341/05 Laval un Partneri Ltd v Svenska Byggnadsarbetareförbundet, Svenska

Byggnadsarbetareförbundets avdelning 1, Byggettan and Svenska Elektrikerförbundet [2007] ECR I-11767. 


\begin{tabular}{|c|c|c|c|c|c|}
\hline $\begin{array}{l}\text { Case C-493/99 } \\
\text { Comn v Germany }\end{array}$ & $\begin{array}{l}\text { Services } \\
\text { (posting) } \\
\text { Establish- } \\
\text { ment }\end{array}$ & & & $x$ & $\begin{array}{l}x \\
x\end{array}$ \\
\hline $\begin{array}{l}\text { Case C-279/00 } \\
\text { Comn v Italy }\end{array}$ & services & & & & $x$ \\
\hline $\begin{array}{l}\text { Case C-445/03 } \\
\text { Comn v } \\
\text { Luxembourg }\end{array}$ & $\begin{array}{l}\text { Services } \\
\text { (posting) }\end{array}$ & & & & $x$ \\
\hline $\begin{array}{l}\text { Case C-490/04 } \\
\text { Comn v Germany }\end{array}$ & $\begin{array}{l}\text { Services } \\
\text { (posting) }\end{array}$ & $\begin{array}{l}\text { X (Commission } \\
\text { produced no } \\
\text { evidence) } \\
\text { X }\end{array}$ & $x$ & & \\
\hline $\begin{array}{l}\text { Case C-112/05 } \\
\text { Comn v Germany }\end{array}$ & Capital & & & & $x$ \\
\hline $\begin{array}{l}\text { Case C-244/04 } \\
\text { Comn v Germany }\end{array}$ & $\begin{array}{l}\text { Services } \\
\text { (posting) }\end{array}$ & & & & $\begin{array}{l}x \\
x\end{array}$ \\
\hline $\begin{array}{l}\text { Case C-168/04 } \\
\text { Comn v Austria }\end{array}$ & $\begin{array}{l}\text { Services } \\
\text { (posting) }\end{array}$ & & & & $x$ \\
\hline $\begin{array}{l}\text { Case C-319/06 } \\
\text { Comn v Lux }\end{array}$ & services & & $\begin{array}{c}\mathrm{X} \\
\text { (insufficient } \\
\text { transparency } \\
\text { ) }\end{array}$ & $x$ & \\
\hline $\begin{array}{l}\text { Case C-577/10 } \\
\text { Comn v Belgium }\end{array}$ & Services & & & & $x$ \\
\hline
\end{tabular}

Table 1 The outcome in Article 258 TFEU cases where the Member States raised worker protection as a justification

A simple win/lose analysis is harder to conduct in the case of the 22 Article 267 references since, by their very nature, the final decision on the compatibility of national law with EU law should be taken by the national courts. Nevertheless, sometimes the Court makes clear that the host state has won or lost, or at least sends a clear signal in that direction. In order to reflect this in the analysis, the cases were categorised as:

(1) those cases where the Court made it very clear that the national rule was lawful ('state wins');

(2) those where the Court gave an indication that the state rule was justified and proportionate ('likely state wins');

(3) those cases where the Court made it clear that the state rule could not be justified ('state loses');

(4) those where it gave a strong indication to that effect ('likely state loses'); and

(5) those cases where the outcome was not clear. 
The application of these categories can be seen in table 2, columns 2-6.

\begin{tabular}{|c|c|c|c|c|}
\hline Case & $\begin{array}{l}\text { State } \\
\text { wins/likely } \\
\text { state wins }\end{array}$ & $\begin{array}{l}\text { State loses: } \\
\text { No justification } \\
\text { offered or } \\
\text { available }\end{array}$ & $\begin{array}{l}\text { State loses: } \\
\text { Justification not made } \\
\text { out }\end{array}$ & $\begin{array}{l}\text { State loses: } \\
\text { Measure disproportionate }\end{array}$ \\
\hline Oebel & $\mathrm{X}$ & & & \\
\hline Webb & $x^{52}$ & & & \\
\hline Seco & & & $x$ & \\
\hline Rush Portuguesa & & & $\mathrm{x}$ & \\
\hline Marchandise & $\mathrm{x}$ & & & \\
\hline Van der Elst & & & $x$ & {$[\mathrm{X}]$} \\
\hline Guiot & & & $x$ & \\
\hline Arblade & $x$ & & $\mathrm{x}$ & $\mathrm{X}$ \\
\hline Mazzoleni & & & & $x^{53}$ \\
\hline \multicolumn{5}{|l|}{ Finalarte } \\
\hline Toolex Alpha AB & $\mathrm{x}$ & & & \\
\hline Portugaia Constr. & & $X$ & & $x$ \\
\hline Uberseering & & & $x$ & \\
\hline PDS & & & & $x$ \\
\hline Wollf \& Muller & $x^{54}$ & & & \\
\hline Laval & & & $x^{55}$ & \\
\hline Viking & & & $x^{56}$ & $x^{57}$ \\
\hline Rüffert & & & & $\mathrm{x}$ \\
\hline Santos Palhota & & & & $x$ \\
\hline Las & & & & $x$ \\
\hline Bundesruckerei & & & & $x$ \\
\hline De Clercq & $x^{58}$ & & & \\
\hline \multicolumn{5}{|c|}{ Table 2: The outcome in Article 267 TFEU references when states raised the worker protection justification } \\
\hline \multicolumn{5}{|c|}{$\begin{array}{l}\text { A summary of the reasons given by the Court as to why the state lost (no justification offered, } \\
\text { justification not made out, national measure not proportionate) can be found in Table } 3 \text {. }\end{array}$} \\
\hline \multirow[t]{6}{*}{ Outcomes } & & & \multicolumn{2}{|c|}{ Number of cases } \\
\hline & \multicolumn{4}{|c|}{ State wins } \\
\hline & \multicolumn{2}{|c|}{ State wins totally } & \multicolumn{2}{|c|}{3} \\
\hline & \multicolumn{2}{|c|}{ State wins in part } & \multicolumn{2}{|c|}{1} \\
\hline & \multicolumn{2}{|c|}{ Likely state wins } & \multicolumn{2}{|c|}{4} \\
\hline & \multicolumn{2}{|c|}{ Likely state wins in part } & \multicolumn{2}{|c|}{1} \\
\hline
\end{tabular}

\footnotetext{
52 Although ultimately left to the national court to decide.

${ }^{53}$ Strong likelihood national rule not proportionate.

${ }^{54}$ Proportionality left to the national court, but with suggestion measure is lawful.

${ }^{55}$ Defendants were trade unions, not the state.

${ }^{56}$ Defendants were trade unions, not the state. Justification ultimately left to the national court to decide

${ }^{57}$ Proportionality left to the national court to decide.

${ }^{58}$ Strong hint national measure proportionate
} 


\begin{tabular}{|c|c|c|}
\hline & Total & 9 \\
\hline \multicolumn{3}{|c|}{ State loses } \\
\hline & State loses totally & 13 \\
\hline & State loses in part & 1 \\
\hline & Likely state loses & 2 \\
\hline & Total & 16 \\
\hline Unclear & & 2 \\
\hline
\end{tabular}

Table 3 Summary of outcomes in the Article 267 TFEU cases

Table 3 shows us that, at its broadest, the states lost in 16 cases and won in 9. Table 4 shows that generally states lost either because they failed to substantiate the justification (approximately 8 cases) or the steps taken were not proportionate (approximately 9 cases). From this, we can say that the state loses in nearly double the number of cases than it wins. If, for reasons explained below, the goods cases are removed (Oebel, Merchandise and Toolex Alpha), the figure of 9 for 'state wins' is reduced to 6 , as compared to 16 'state loses'. If we look at 'state wins totally' and add to this the figures for the state wins in enforcement proceedings, states win in 4 cases (three Article 267 TFEU references, one Article 258 TFEU enforcement proceedings) and lose in 22 cases. This gives a win: lose ratio of 2:11. Putting it another way states win in $15 \%$ of cases and lose in $85 \%$ of cases.

Although this analysis may seem crude, the raw data is overwhelming. The quantitative analysis supports the view that the Court is impatient when states raise the worker protection justification as a limitation on free movement rights. ${ }^{59}$ Putting it another way, the quantitative data suggests that worker protection is being marginalised in favour of broader arguments based on worker welfare, although the Court has never made this point explicitly. However, appearances can be deceptive. The discussion below suggests the reality is more complex. It will be argued that a distinction needs to be drawn between those cases where the justification is invoked to protect the national worker in the face of challenges to national rules, often by business using the four freedoms (section D) and those where the worker protection justification is invoked in the context of migration, particularly by workers under Article 45 TFEU or by companies providing services using posted workers under Article 56 TFEU (section E). In cases involving national workers and a more traditional labour law context (worker v employer) the Court seems more willing to uphold the worker protection justification than in the cases involving migration, provided there are genuine worker protection

\footnotetext{
${ }^{59}$ Earlier research tends to support this view more generally in the field of justifications: C. Barnard, Derogations, Justifications and the Four Freedoms: Is State Interest Really Protected?' in C. Barnard and O. Odudu, The Outer Limits of European Union Law (Oxford, Hart Publishing, 2009).
} 
concerns. While the dynamic is more complex in cases involving migrant/posted workers even here the Court may be more willing to accept the worker protection justification where there are genuine concerns about ensuring that migrating workers enjoy employment protection.

\section{The 'National' Worker Cases}

\section{Introduction}

In this section, we look at those cases where the state is invoking the worker protection justification on behalf of (mainly) national workers against claims based on free movement (of goods, establishment, services and capital) brought by business (or by the Commission on behalf of business seeking to ensure their free movement rights). It will be argued that these cases show that, provided a genuine claim is made by the defendant state, the Court has broad sympathy with the worker protection justification and will prioritise it. The testing ground for this argument is the free movement of goods, where the earliest cases arose.

\section{Free movement of goods}

In respect of free movement of goods, when host states invoke national rules to protect national consumers from imports, the Court is generally sceptical. Most famously, as we saw in in Cassis de Dijon, the Court rejected the German justification that consumers would be protected by a prohibition on the import of the weaker French cassis; access to those goods combined with adequate labelling would be a more proportionate response. In this way, consumer welfare would be increased given the greater choice that free movement of goods would bring to consumers. This is not an isolated example: rules limiting the ingredients in beer ${ }^{60}$ and pasta, ${ }^{61}$ all justified on the grounds of consumer protection/public health, were successfully challenged as being contrary to Article 34 TFEU, as were controls on advertising that claimed to protect consumers but were in reality placing unfair limits on competition. ${ }^{62}$ In these cases consumer welfare prevailed over consumer protection.

By contrast, in the three free movement of goods cases where worker protection was at issue, the Court has favoured worker protection over worker welfare. First, in Oebel, ${ }^{63}$ considered above, the

\footnotetext{
${ }^{60}$ Case C-178/84 Commission v Germany [1987] ECR 1227.

${ }^{61}$ Case C-202/82 Commission v France [1984] ECR 933; Case C-90/86 Zoni [1988] ECR 4285.

${ }^{62}$ Case C-210/96 Gut Springenheide [1998] ECR I-4657; C-303/97 Kessler [1999] ECR I-513; Case C-220/98 Estée Lauder [2000] ECR I-117.

${ }^{63}$ Case 155/80 Summary proceedings against Sergius Oebel [1981] ECR 1993.
} 
Court ruled that the restriction on night-working did not breach Article 34 TFEU because the rules were non- discriminatory, and the restrictions on transport and delivery did not affect trade between Member States. The Court also noted the special nature of the sector:the prohibition in the bread and confectionery industry on working before 4 a.m. is' designed to improve working conditions in a manifestly sensitive industry, in which the production process exhibits particular characteristics resulting from both the nature of the product and the habits of consumers'. ${ }^{64}$ Second, Marchandise ${ }^{65}$ concerned a French law prohibiting the employment of staff on Sundays after 12 noon. This case was part of the rather obscure series of decisions on Sunday trading which ultimately led to the Keck 'revolution' ${ }^{66}$ For the purposes of this chapter, the interesting point is that the Court emphasised the autonomy of the national social legislation:

national rules governing the opening hours of retail premises reflect certain political and economic choices in so far as their purpose is to ensure that working and non-working hours are so arranged as to accord with national or regional socio-cultural characteristics, and that, in the present state of [Union] law, is a matter for the Member States.

The Court concluded that the 'restrictive effects on trade which may stem from such rules do not seem disproportionate to the aim pursued' ${ }^{67}$

Third, Toolex Alpha ${ }^{68}$ concerned national rules which included a general prohibition on the industrial use of trichloroethylene. The Court said the system of individual exemptions, granted subject to conditions, established by the Swedish regulation appeared 'appropriate and proportionate in that it offers increased protection for workers, whilst at the same time taking account of the undertakings' requirements in the matter of continuity.' The Court referred to a range of EU health and safety legislation to support its conclusion. ${ }^{69}$

These three cases suggest a prioritising of worker protection over the Union interest in creating the single market, although the sample size is too small to make such a generalisaiton with confidence. It should also be noted that in Oebel and Marchandise the facts hovered on the outer edges of EU law

64 Para. 12.

${ }^{65}$ Case C-332/89 [1991] ECR I-1027.

${ }^{66}$ N. Reich, 'The "November revolution" of the European Court of Justice: Keck, Meng and Audi Revisited' (1994) 31 CMLRev. 459

67 Para. 13.

${ }^{68}$ Case C-473/98 Kemikalieinspektionen v Toolex Alpha AB [2000] ECR I-5681.

69 Para. 47. 
and Toolex Alpha concerned a product raised serious health concerns. Nevertheless, we can say that in these few cases where worker protection has been raised, unlike in the field of consumer law, the Court seemed keen to protect the weaker party in the face of (aggressive?) single market challenges from business.

\section{The other freedoms}

The position is somewhat different in respect of the other freedoms. There are four cases - two on freedom of establishment (Uberseering ${ }^{70}$ and Payroll Data Services (PDS) ${ }^{71}$ ), one on capital (Case C112/05 Commission v Germany (Volkswagen) ${ }^{72}$ ) and one on free movement of services $\left(\right.$ Webb $\left.^{73}\right)$ where the defendant state invoked worker/employee protection as a justification for its rules protecting national workers in the face of challenges by business/the Commission. In only one of the cases $($ Webb) did the Court suggest that the justification was made out.

In both Uberseering and Volkswagen, the Court considered that the defendant state had failed to make out the link between the measure adopted and the justification alleged. Uberseering concerned a German rule which denied the legal capacity and, consequently, the capacity to be a party to legal proceedings, to a company properly incorporated in the Netherlands where it had its registered office. The Court said that such a measure was tantamount to an outright negation of the freedom of establishment conferred on companies by Articles 49 TFEU and 54 TFEU. ${ }^{74}$ The Court said that 'It is not inconceivable that overriding requirements relating to the general interest, such as the protection of the interests of creditors, minority shareholders, employees and even the taxation authorities, may, in certain circumstances and subject to certain conditions, justify restrictions on freedom of establishment ${ }^{75}$ but this was not the case on the facts. ${ }^{76}$

Commission v Germany concerned the German Volkswagen law limiting the voting rights of every shareholder to $20 \%$ of Volkswagen's share capital, requiring a majority of over $80 \%$ of the shares represented for resolutions of the general assembly, and allowing, in derogation from the general law, the Federal State and the Land of Lower Saxony each to appoint two representatives to the company's supervisory board. The Court found these rules breached Article 63 TFEU. On the

\footnotetext{
${ }^{70}$ Case C-208/00 Uberseering v Nordic Construction Company Baumanagement GmbH [2002] ECR I-9919.

${ }^{71}$ Case C-79/01 Payroll Data Services

72 [2007] 1-8995

${ }^{73}$ Case 279/80 Webb [1981] ECR 3305

${ }^{74}$ Case C-208/00 Uberseering [2002] ECR I-9919, para. 93

${ }^{75}$ Emphasis added.

${ }^{76}$ Para. 92.
} 
question of justification and proportionality, the Court said that Germany had been unable to explain, 'beyond setting out general considerations as to the need for protection against a large shareholder which might by itself dominate the company, why, in order to meet the objective of protecting Volkswagen's workers, it is appropriate and necessary for the Federal and State authorities to maintain a strengthened and irremovable position in the capital of that company'. ${ }^{77}$ In the third case, $P D S,{ }^{78}$ the Court thought the host state's rules were out of date and inconsistent. National legislation required that undertakings with fewer than 250 employees, which wished to entrust the preparation and printing of their pay slips to data processing centres (DPCs), could have recourse only to those DPCs established and staffed exclusively by persons registered with certain professional bodies in Italy. This requirement did not apply where DPCs offered their services to undertakings with more than 250 employees. The Court said that 'since the tasks in question cannot be any less complex when the number of salaried staff concerned increases, the disputed provision goes, in any event, beyond what is necessary to attain its objective of protection. ${ }^{79}$

In Webb, by contrast, as we saw above, the Court was sympathetic to the worker protection justification, particularly having emphasised (as in Oebel) the sensitivity of the sector (temp agencies) $\cdot{ }^{80}$ Nevertheless, the Court required the national court to check that, in granting licences, the host state (1) did not discriminate on the grounds of nationality, and (2) took into account the evidence and guarantees already produced by the provider of the services for the pursuit of his activities in the home state. ${ }^{81}$

\section{Preliminary conclusions}

Thus the tenor of Webb fits with the dominant worker protection theme found in the three cases on free movement of goods; the Court considered that there was a genuine concern about workers who needed protection. The failure of the worker protection justification in the establishment and capital cases can be explained more on the basis of the Court's general jurisprudence on limitations on the use of justifications field (see section $B$ above) than by any outright rejection of the worker protection justification (namely, the states failed to make a proper case, to be consistent and to act proportionately). Taken as a whole, these seven cases (three goods, two establishment, one capital, one services) point to the

\footnotetext{
77 Para. 74.

${ }^{78}$ Case C-79/01 Payroll Data Services

79 Para. 37.

${ }^{80}$ Para. 18. This is still the case: agency work was excluded from the provisions of the Services Directive.

${ }^{81}$ Para. 21
} 
provisional conclusion that, provided the thresholds outlined in section B are satisfied, the Court is broadly sympathetic to claims based on worker protection raised in standard labour law situations (business $v$ national worker).

\section{E. Migrant and posted worker cases}

\section{Prioritising of worker welfare}

We now turn to focus on those cases where one group of workers' interests (generally poorer but ambitious migrant workers) are being pitted against another group (generally the immobile, possibly unionised, national workers). In these cases the state may raise the worker protection justification ostensibly to protect the (migrant) workers' interests but in fact also as a cover to protect the national workers' interests, specifically their jobs. While the state's positon is understandable, the Court is sensitive to 'worker protection' being used either to obstruct free movement or, worse from an EU point of view, as a form of protectionism. In these cases, the Court will reject the state's justification and so deliver worker welfare, namely the opportunity for workers to improve their life chances through employment in other Member States, either as migrant workers under Article 45 TFEU or posted workers under Article 56 TFEU. ${ }^{82}$

$\operatorname{Las}^{83}$ is a good example of worker protection being used to obstruct free movement. The case concerned a Flemish law providing that only the Flemish text of a cross-border employment contract was authentic (and not, for example, a text in English). Belgium sought to justify its requirement on the basis of the need to ensure 'the protection of employees by enabling them to examine employment documents in their own language and to enjoy the effective protection of the workers' representative bodies and administrative and judicial bodies called upon to recognise those documents, and, finally, to ensure the efficacy of the checks and supervision of the employment inspectorate'. While the Court recognised worker protection as a justification, it found the rules disproportionate. The establishment of free and informed consent between the parties required

\footnotetext{
82 On the difficulties of balancing these competing interests and how the Charter has not, so far, been of much assistance, see C. Barnard, 'The Silence of the Charter' in S. De Vries, U. Bernitz and S. Weatherill, 'The EU Charter of Fundamental Rights as a Binding Instrument: Five Years Old and Growing' (Oxford, Hart Publishing, 2015).

${ }^{83}$ Case C-202/11 Las v PSA Antwerp NV EU:C:2013:239
} 
those parties to be able to draft their contract in a language other than the official language of Belgium. ${ }^{84}$

In some of the cases involving posted workers the Court also seems to consider the worker protection justification as coming closer to protectionism. The Court therefore rejects it outright or finds the steps taken to be disproportionate. So, for example, the Court said that host state laws requiring the posted worker to have been employed by the service provider for at least 6 months in the case of Luxembourg ${ }^{85}$ (a year in the case of Germany) ${ }^{86}$ were not lawful. A requirement for the posted workers to have individual work permits which were only granted where the labour market situation so allowed was also not compatible with the EU law. ${ }^{87}$ The Court has also said that a requirement for the service provider to provide, for the purposes of obtaining a work permit, a bank guarantee to cover costs in the event of repatriation of the worker at the end of his deployment was not permitted, ${ }^{88}$ nor was a requirement that the work be licensed, ${ }^{89}$ nor was a rule that in order for an EU posting confirmation to be issued, the posted worker must have been employed by the sending company for at least a year previously and to have an indefinite contract with that company. $^{90}$

Perhaps, most extreme was Case C-445/03 Commission v Luxembourg ${ }^{91}$ concerning a requirement, that posted workers had employment contracts of indefinite duration in force for at least six months with their employer in the state of origin. Luxembourg argued that this rule addressed the risk of abusive exploitation of workers from non-member countries through the use of precarious and poorly-remunerated contracts while also protecting against the dangers of distortion of competition through social dumping. ${ }^{92}$ The Court rejected this argument. It said that the Luxembourg rule could not be regarded as constituting an appropriate means since it involved formalities and periods which

\footnotetext{
${ }^{84}$ Para. 31

${ }^{85}$ Case C-445/03 Commission v. Luxembourg [2004] ECR I-10191, paras. 32-3.

${ }^{86}$ Case C-244/04 Commission v. Germany [2006] ECR I-885

${ }^{87}$ Case C-445/03 Commission v. Luxembourg [2004] ECR I-10191, paras. 42-3. See also Case C-43/93 Vander Elst [1994] ECR I-3803.

88 Ibid., para. 47.

${ }^{89}$ Ibid., para. 30.

${ }^{90}$ Case C-168/04 Commission v. Austria [2006] ECR I-9041.

${ }^{91}$ Case C-445/03 Commission v Luxembourg [2004] ECR I-10191.

92 Para. 28
} 
were 'liable to discourage the free provision of services through the medium of workers who are nationals of non-member countries'.$^{93}$ Once again, worker welfare prevails.

The Court has also considered control measures in cases not involving posted workers. So, in Case C$577 / 10$ Commission v Belgium, ${ }^{94}$ the Court found a Belgian requirement, imposing on migrant selfemployed service providers the obligation to make a prior declaration, breached Article 56 TFEU. Although the Court recognised that the 'objective of combating fraud, particularly social security fraud, and preventing abuse, in particular detecting 'bogus self-employed persons' and combating undeclared work, can form part not only of the objective of the financial balance of social security systems, but also of the objectives of preventing unfair competition and social dumping and protecting workers, including self-employed service providers', the 'very detailed information' required was disproportionate. ${ }^{95}$

Protecting national jobs was also the motivating force behind the trade unions' decisions to call their members out on strike in the well-known cases of Viking ${ }^{96}$ and Laval ${ }^{97}$. In Laval, the Court recognised 'the right to take collective action for the protection of the workers of the host State against possible social dumping may constitute an overriding reason of public interest' ${ }^{98}$ However, it said that on the facts the collective action could not be justified where the negotiations on pay, formed part of a national context characterised by a lack of provisions, of any kind, which were sufficiently precise and accessible that they did not render it impossible or excessively difficult in practice for such an undertaking to determine the obligations with which it was required to comply as regards minimum pay. ${ }^{99}$ In Viking, the Court recognised the Finnish trade unions' right to take strike action to protest at the loss of jobs to Estonia but only where strict conditions were satisfied and the strike action was the last resort. These points were left to the national court to decide (the case was eventually settled) but there is a sense in the judgment that the unions were unlikely to make out either the

\footnotetext{
93 Para. 30

${ }^{94} \mathrm{EU}: \mathrm{C}: 2012: 814$, para.45.

95 Para. 56.

${ }^{96}$ Case C-438/05 International Transport Workers' Federation and Finnish Seamen's Union [2007] ECR I-10779.

${ }^{97}$ Case C-341/05 Laval un Partneri Ltd v Svenska Byggnadsarbetareförbundet, Svenska Byggnadsarbetareförbundets avdelning 1, Byggettan and Svenska Elektrikerförbundet [2007] ECR I-11767.

There is now an enormous literature on these cases. For a good overview of the debate see M. Freedland and J. Prassl, Viking, Laval and beyond (Oxford, Hart Publishing, 2014).

${ }^{98}$ Para. 103.

${ }^{99}$ Para. 110. For further analysis of Dir 96/71 see Case C-346/06 Rüffert v. Land Niedersachsen [2008] ECR I1989.
} 
justification or the proportionality test. Once again, it seems that in these cases worker welfare prevailed over state/trade union interest in worker protection.

\section{A more nuanced approach.}

The general tenor of the cases considered so far in this section suggests that, unlike in the cases involving national workers, there is a prioritising of worker welfare (of migrant or posted workers) over worker protection. However, there are cases where the Court demonstrates, as it did in the national worker cases Oebel and Webb, an awareness that migrant and posted workers risk exploitation. So, for example, in Guiot, the Court talked of the social protection of workers in the construction industry [which] may however, because of conditions specific to that sector, constitute an overriding requirement justifying a restriction on the freedom to provide services. ${ }^{100}$ And given the risks facing posted workers in these sectors 'control measures' such as inspection requirements, document checks and the like, may need to be put in place by the host state as the Court recognised in Arblade: ${ }^{101}$

The effective protection of workers in the construction industry, particularly as regards health and safety matters and working hours, may require that certain documents are kept on site, or at least in an accessible and clearly identified place in the territory of the host Member State, so that they are available to the authorities of that State responsible for carrying out checks, particularly where there exists no organised system for cooperation or exchanges of information between Member States as provided for in Article 4 of Directive $96 / 71 .{ }^{102}$

The importance of proportionate control measures is in fact a theme of a number of posted workers cases. For example, in Case C-244/04 Commission v. Germany, ${ }^{103}$ the Court said that the host state could insist that the service provider furnished a 'simple prior declaration certifying that the situation of the workers concerned is lawful', particularly in the light of the requirements of residence, work visas and social security cover in the Member States where the provider employs

\footnotetext{
100 Para. 16 (emphasis added). See also Finalarte, para. 69.

101 Joined Cases C-369/96 and C-376/96 Arblade and Others [1999] ECR I-8453.

102 Para. 61.

${ }^{103}$ Case C-244/04 Commission v. Germany [2006] ECR I-885, confirmed in Case C-219/08 Commission v.

Belgium [2009] ECR I-9213.
} 
them. ${ }^{104}$ In Case C-445/03 Commission v. Luxembourg ${ }^{105}$ the Court said that the host state could require the service provider to report beforehand to the local authorities on the presence of one or more posted workers, the anticipated duration of their presence and the provision or provisions of services justifying the deployment ${ }^{106}$ and, in Case C-490/04 Commission v. Germany, ${ }^{107}$ that the host state could require a (reasonable) number of those documents to be translated into German.

\section{Preliminary conclusions}

In conclusion, the general tenor of the case law involving migrant and posted workers has been to favour worker welfare over worker protection, a view borne out by the quantitative analysis. This is particularly so in cases involving what the Court considers to be protectionism by the host state. It is also true that, in respect of cases involving antiquated rules which may have lost their original rationale, the Court will reject the worker protection justification. We saw this in Las and Seco. It can also be seen in Case C-493/99 Commission v Germany where German law said that companies could not provide trans-frontier services on the German market as part of a consortium unless they had their seat, or at least an establishment, in Germany employing their own staff, and had concluded a company-wide collective agreement for those staff. The Court found such rules constituted a clear breach of the Treaty provisions on free movement of services.

However, where there are genuine concerns about potential abuse or mistreatment of migrant or posted workers the Court will uphold proportionate control measures (mainly against the backcloth of the Posted Workers Directive 96/71, ${ }^{108}$ which allows host states to insist on applying the substance of its rules, but does not cover control measures to ensure those rules and others are enforced $\left.^{109}\right)$. Indeed, in its case law on control measures the Court comes close to providing a legislative catalogue as to what is - and is not - acceptable in the name of worker protection. Paradoxically, the decisions (considered in section E.1) which apparently favour worker welfare may go some way to promoting worker protection in future situations, not just of national workers but of migrant/posted workers. By giving a detailed consideration of, say, the proportionality criteria, the Court is essentially providing the host state with a template as to what it can lawfully do in the

${ }^{104}$ However, the host state cannot require the declaration to be sent in advance so that a registration number can be issued without which the planned posting cannot take place: Case C-515/08 Santos Palhota [2010] ECR I-9133.

${ }^{105}$ Case C-445/03 [2004] ECR I-10191.

${ }^{106}$ Para. 31.

${ }^{107}$ Case C-490/04 Commission v. Germany [2007] ECR I- 6095, para. 76.

108 OJ [1997] L18/1.

${ }^{109}$ Cf Directive 2014/67 on the enforcement of Directive 96/71 (OJ [2014] L159/11). 
future to protect vulnerable posted workers. Thus, once again, in these cases the Court's approach upholds the function of labour law, protecting the weaker party (ie the domestic or migrant worker). In these situations there is therefore not so much difference between the cases involving domestic workers (section D) and those involving migrant/posted workers (section E). A qualitative analysis of the cases therefore suggests that the Court is trying to strike a careful balance between, on the one hand, protecting workers and, on the other, preventing protectionism. Putting it succinctly, in appropriate cases the Court does allows worker protection but not protectionism.

\section{F. Conclusions}

The aim of this chapter has been to explore the 'face' of the worker in the Court's case law on 'worker protection' justifications. Drawing on the analysis of the Court's case law on the 'consumer protection' justification, the chapter has made a distinction between cases which support worker protection (ie upholding paternalist national legislation protecting individual workers) and those which uphold worker welfare (ie removing national legislation which protects workers in the name of allowing EU workers to benefit from free movement).

A bare statistical analysis suggests that the Court's case law does lead to the prioritisation of worker welfare over worker protection, in much the same way as the Court's consumer case law prioritises consumer welfare over consumer protection. The Court does have acute antennae for rules, justified in the name of worker protection, which in fact have passed their sell-by date or are protectionist of the national market. It has therefore used the Euro-worker, in much the same way as it has the Euroconsumer 'as a lever to prise open markets sheltered by national regulation'. ${ }^{110}$

However, a closer analysis of the case law suggests that, in fact in genuine cases, the Court is sensitive to the worker protection objectives of national legislation and will uphold the national rules (eg in cases involving particular types of work or sectors and, in respect of posted workers, ${ }^{111}$ proportionate control measures) or will at least indicate how existing national rules can be made more proportionate to secure worker protection. It is therefore misleading to see all the cases where states 'lost' as a triumph of worker welfare over worker protection.

Thus while insights from the consumer literature have been helpful in unpacking what is actually going on in the Court's case law in the cases involving workers, it is important to recognise the

\footnotetext{
${ }^{110}$ S. Weatherill, 'Consumer Policy' in P. Craig and G. de Búrca Evolution of EU Law, (Oxford, OUP, 2011), 843.

${ }^{111}$ Where the Court does uphold the worker protection justification raised by the host state, it allows states to protect not just national but also migrant/posted workers. With the consumer protection justification, the beneficiaries are mainly the national consumers.
} 
differences too between consumers and workers. The first concerns winners and losers. Consumers are the passive beneficiaries of the single market: they are either being protected from 'bad' goods produced elsewhere (consumer protection prevails) or they can access goods produced elsewhere (consumer welfare prevails). By contrast, workers under Article 45 TFEU, and posted workers under Article 56 TFEU, are active beneficiaries of the single market. They are doing exactly what the Treaty envisages. For individual migrant/posted workers the worker welfare approach is advantageous; for weak, ill-educated individual consumers, the consumer welfare approach may be disadvantageous.

The second concerns the social consequences of prioritising consumer/worker welfare. In the field of goods or services, there is an assumption of almost unlimited supply and that consumers are not competing with each other for particular products. This may not be the case with jobs, especially in a contracting economy. In the case of scarcity, the loss of a product may be upsetting to a consumer; the loss of a job may be devastating to (ex-) workers and their families. So the opening up of the fruit liqueur market in the name of consumer welfare is a win for consumers (although not necessarily in the longer term for the domestic manufacturers and their workers). By contrast, the opening up of the services market is a win for the migrant (posted) worker but may be a loss for the non-migrant worker. These arguments of substitution are contested but they are politically and psychologically resonant. ${ }^{112}$ For this reason, when the Court prioritises worker welfare over worker protection there may be serious political consequences, as the aftermath of the judgments in Laval and Viking have shown.

The third concerns the regulatory consequences of a decision to prioritise consumer/worker welfare. The removal of regulatory barriers created by national consumer protection legislation in the name of consumer welfare can be serious but compensated for to a large extent by reregulating at EU level. This is not the case with employment law and policy. The removal of any national social law in recent years has not been matched by re-regulation at EU level. Despite the expansion of EU competence in the social field, this has not been matched by an increased political will to use that increased competence. ${ }^{113}$ As the Monti ${ }^{114}$ debacle has so clearly shown, ${ }^{115}$ it is very difficult to

\footnotetext{
${ }^{112}$ See eg J. Kawalerowicz, 'Perception of immigration level, rather than actual change in local areas, explains the UKIP vote, LSE EUROPP, http://blogs.Ise.ac.uk/europpblog/2015/06/04/perception-of-immigration-levels rather-than-actual-change-in-local-areas-explains-the-ukipvote/?utm_source=feedburner\&utm_medium=email\&utm_campaign=Feed\%3A+Europp+\%28EUROPP++European+Politics+and+Policy+at+LSE\%29

${ }^{113}$ See C. Barnard, EU Employment Law (Oxford, OUP, 2012), chaps. 1 and 2.

${ }^{114}$ COM(2012) 130.
} 
reach agreement at EU level on new substantive social legislation (with the exception of legislation on enforcement). ${ }^{116}$ So to proponents of the maintenance of national social models, the removal of any national social rules in the name of worker welfare is a further nail in the coffin of social structures which have been built up over decades as part of the fabric of national life. Sometimes, as in Spain and Italy, that fabric may become a straitjacket for adapting to modern conditions. In other countries, such as Germany that infrastructure may be one of the explanations for its economic success. ${ }^{117}$ The Court must tread carefully; this chapter shows that in many - but not all - cases it does.

\footnotetext{
${ }^{115}$ See further M. Freedland and J. Prassl, Viking, Laval and beyond (Oxford, Hart Publishing, 2014), especially chap. 5 .

${ }^{116}$ Although cf the new proposal on Posted Workers: $\operatorname{COM}(2016) 128$. Nine Member States have come out to say they are opposed to the measure.

${ }^{117}$ See P. Hall and D. Soskice, 'An Introduction to Varieties of Capitalism' in B. Hancké (ed), Debating Varieties of Capitalism: A Reader (Oxford, OUP, 2009).
} 